\title{
ANALISIS KEMAMPUAN PENALARAN MATEMATIS PADA MATA KULIAH ALJABAR LINEAR ELEMENTER MAHASISWA PENDIDIKAN MATEMATIKA FAKULTAS TARBIYAH DAN KEGURUAN UIN ALAUDDIN MAKASSAR
}

\section{ANALYSIS OF MATHEMATICS REASONING ABILITY IN ELEMENTARY LINEAR ALGEBRA COURSE STUDENTS OF MATHEMATICS EDUCATION FACULTY OF TARBIYAH AND TEACHER TRAINING AT UIN ALAUDDIN MAKASSAR}

\author{
Nur Yuliany'), Andi Halimah'2), Feby Manzila3), Nidya Nina Ichiana4) \\ 1,2,3,4)Fakultas Tarbiyah dan Keguruan Universitas Islam Negeri Alauddin Makassar

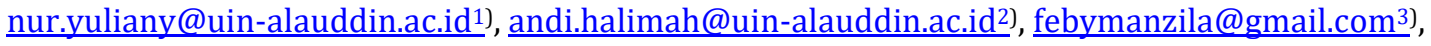 \\ nidyanina.ichiana@uin-alauddin.ac.id ${ }^{4}$ )
}

\begin{abstract}
Abstrak
Penelitian ini bertujuan untuk mengetahui kemampuan penalaran matematis dan mengetahui faktor-faktor yang memengaruhi kemampuan penalaran matematis dalam mata kuliah Aljabar Linear Elementer mahasiswa. Penelitian ini menggunakan pendekatan deskriptif kualitatif menggunakan pupulasi semua mahasiswa angkatan 2017 dengan sampel 72 orang. Teknik pengumpulan data secara tes tertulis, wawancara dan dokumentasi, dengan teknik analisis statistic deskriptif. Hasil yang diperoleh adalah kemampuan penalaran matematis mahasiswa semester II Jurusan Pendidikan Matematika berada pada kategori sedang. Berdasarkan indikator kemampuan penalaran matematis mahasiswa jika dirata-ratakan persentasenya adalah 51,52\%. Meskipun terbilang sedang, masih banyak kemampuan-kemampuan yang ditemukan masih tergolong rendah. Indikator yang paling tinggi berada pada kemampuan menarik kesimpulan logis yaitu sebesar $76,53 \%$. Faktor-faktor yang memengaruhi kemampuan penalaran matematis pada mata kuliah Aljabar Linear Elementer mahasiswa semester II Jurusan Pendidikan Matematika adalah faktor internal yaitu minat dan konsentrasi, dimana dalam meningkatkan pemahaman logika mahasiswa, hal ini tentunya berkaitan dengan meningkatkan daya nalar. Hal yang serupa terdapat pada disiplin ilmu matematika yang mampu membuat nalar mahasiswa semakin kritis. Selanjutnya faktor eksternal yaitu perangkat pembelajaran, peran dosen dan lingkungan belajar.
\end{abstract}

Kata Kunci: kemampuan, penalaran matematis, aljabar linear elementer

\begin{abstract}
This study aims to determine the ability of mathematical reasoning and to determine the factors that influence the ability of mathematical reasoning in the Elementary Linear Algebra course of students. This study uses a qualitative descriptive approach using a population of all 2017 students with a sample of 72 people. Data collection techniques are written tests, interviews and documentation, with descriptive statistical analysis techniques. The results obtained are the mathematical reasoning abilities of second semester students of the Mathematics Education Department are in the medium category. Based on the indicators of students' mathematical reasoning abilities, if the average percentage is $51.52 \%$. Even though it is fairly moderate, there are still many abilities that are found that are still relatively low. The highest indicator is in the ability to draw logical conclusions, which is $76.53 \%$. The factors that influence the mathematical reasoning ability in the Elementary Linear Algebra course for second semester students of the Mathematics Education Department are internal factors, namely interest and concentration, where in improving students' understanding of logic, this is of course related to increasing reasoning power. The same thing is found in the discipline of
\end{abstract}


mathematics which is able to make students' reasoning more critical. Furthermore, external factors are learning devices, the role of lecturers and the learning environment.

Keywords: ability, mathematical reasoning, elementary linear algebra

How to Cite: Yuliany, N., Halimah, A., Manzila, F., \& Ichiana, N.N. (2021). Analisis kemampuan penalaran matematis pada mata kuliah aljabar linear elementer mahasiswa pendidikan matematika fakultas tarbiyah dan keguruan UIN Alauddin Makassar. Al asma: Journal of Islamic Education, 3(2), 275-286.

\section{PENDAHULUAN}

Matematika sebagai suatu disiplin ilmu yang secara jelas mengandalkan proses berpikir, yang didalamnya terkandung sebagai aspek yang secara substansial menuntun siswa untuk berpikir logis menurut pola dan aturan yang telah tersusun baku. Matematika di sekolah mempunyai peranan yang cukup besar dalam kemampuan berpikir memecahkan masalah di kehidupan sehari-hari. Sariningsih \& Purwasih (2017) menyatakan pendidikan matematika dapat mendorong masyarakat untuk selalu maju, terbukti dengan adanya perkembangan teknologi modern. Oleh karena itu, belajar matematika dengan baik merupakan langkah pertama dalam penguasaan konsep.

Salah satu disiplin ilmu yang membuat kita berpikir kognitif adalah pembelajaran matematika. Matematika merupakan disiplin ilmu yang memiliki ciri khas jika dibandingkan dengan disiplin ilmu lain, bisa dikatakan bahwa matematika bersifat abstrak yang memerlukan konsep pemahaman dan proses berpikir yang sistematis.

Anderson dalam Kesumawati (2010) menyatakan "understand is defined as constructing the meaning of instructional messages, including oral, written, and graphic communication". Menurut pendapat tersebut, siswa dikatakan memahami sesuatu jika mereka mampu mengkonstruksi makna dari pesan-pesan pengajaran seperti komunikasi lisan, tulisan, dan grafik. Tingkat pemahaman seseorang terhadap suatu konsep dapat dilihat dari jenis-jenis pemahaman yang dimilikinya.

Dalam meningkatkan pemahaman logika mahasiswa, hal ini tentunya berkaitan dengan meningkatkan daya nalar kritisnya. Hal yang serupa terdapat pada disiplin ilmu matematika yang mampu membuat nalar mahasiswa semakin kritis. Hal ini karena seringnya penggunaan pemikiran-pemikiran yang logis serta sistematis dalam pemecahan soal, apabila dikaitkan dengan solusi pemecahan masalah matematika ditemukan bahwa solusi dari permasalahan cenderung memiliki solusi yang pasti yang menekankan pada proses bernalar.

Menurut Keraf dalam Sumarmo (2016), istilah penalaran serupa dengan pengertian penalaran logis dalam tes Longeot yaitu sebagai proses berpikir yang memuat kegiatan menarik kesimpulan berdasarkan peristiwa yang ada. Kemampuan penalaran (mathematical reasoning) berlangsung ketika seseorang berpikir tentang suatu masalah atau menyelesaikan masalah. Indikator penalaran yang digunakan dalam penelitian ini yaitu memberikan penjelasan dengan menggunakan model fakta, sifat-sifat, dan hubungan, mengikuti argumen logis.

Penalaran matematis merupakan suatu proses penyimpulan fakta, analisa, dan prediksi dalam membuat suatu kesimpulan (Nursalam, Angriani, \& Usman, 2017). Pernyataan yang mendasar penarikan suatu kesimpulan inilah yang dimaksud dengan 
premis atau antesedes. Sedangkan hasilnya, suatu pernyataan baru yang merupakan kesimpulan disebut dengan konklusi atau konsekuens. Dari dua definisi tadi jelas bahwa ada kesamaan antara penalaran dan argumen. Suatu proses berpikir dalam menarik suatu kesimpulan yang berupa pengetahuan disebut penalaran dimana proses di dalamnya yaitu mengumpulkan serta menghubungkan fakta-fakta yang diketahui menuju kepada suatu kesimpulan.

Penalaran matematika merupakan kemampuan menemukan konjektur, analisis, evaluasi, generalisasi, koneksi, sintesis, pemecahan masalah tidak rutin, pembuktian, dan kemampuan komunikasi matematik. Kemampuan-kemampuan tersebut dapat muncul pada saat berpikir tentang suatu masalah atau penyelesaian masalah matematik (Suharnan, 2005). Penalaran matematika merupakan proses berpikir secara logis dalam menghadapi problema dengan mengikuti ketentuan-ketentuan yang ada.

Dalam memahami penalaran mahasiswa dihadapkan pada dua jenis pemahaman yaitu pemahaman instrumen dan pemahaman relasional. Pemahaman instrumental mengarahkan mahasiswa untuk menghasilkan jawaban yang benar karena jenis pemahaman ini menuntut mahasiswa untuk berpikir secara prosedural atau algoritmik. Mahasiswa biasanya dihadapkan hanya pada persoalan rutin sehingga biasanya mahasiswa memiliki kemampuan koneksi yang sangat rendah dan terbatas. Pada umumnya mereka akan kesulitan mengadaptasi suatu permasalahan yang tidak rutin dengan skema yang sudah ada dalam struktur mentalnya. Pemahaman jenis relasional mengarahkan mahasiswa untuk mengaitkan konsep dalam satu topik maupun mengaitkan konsep antar topik. Mahasiswa yang memiliki kemampuan relasional dapat membangun koneksi yang lebih luas untuk membuat kerangka kerja konseptual sehingga dapat membantu mereka dalam mengaplikasikan konsep matematis (Rosita, Laelasari, \& Noto, 2014).

Dalam meningkatkan pemahaman logika mahasiswa, hal ini tentunya berkaitan dengan meningkatkan daya nalar kritisnya. Hal yang serupa terdapat pada disiplin ilmu matematika yang mampu membuat nalar mahasiswa semakin kritis. Hal ini karena seringnya penggunaan pemikiran-pemikiran yang logis serta sistematis dalam pemecahan soal, apabila dikaitkan dengan solusi pemecahan masalah matematika ditemukan bahwa solusi dari permasalahan cenderung memiliki solusi yang pasti yang menekankan pada proses bernalar.

Penalaran matematika penting untuk mengetahui dan mengerjakan matematika. Kemampuan untuk bernalar menjadikan mahasiswa dapat memecahkan masalah matematika yang di dalamnya termasuk menyelesaikan soal matematika yang mengharuskan kita untuk berpikir contohnya menghadapi abstraksi. Belajar untuk berpikir matematika berarti (a) mengembangkan cara pandang matematik, menghargai proses matematisasi dan abstraksi serta memiliki kesukaan menerapkannya, dan (b) mengembangkan kompetensi dengan alat-alat penting, dan menggunakan alat-alat ini dalam memenuhi tujuan struktur pemahaman (Sriyanto, 2007).

Indikator dalam penalaran matematika yaitu menarik kesimpulan logis, memberikan penjelasan dengan menggunakan model, fakta, sifat-sifat, dan hubungan, serta memperkirakan jawaban dan proses solusi. Dalam proses pembelajaran, mahasiswa dituntut memiliki kemampuan untuk menyelesaikan masalah dari materi yang telah diajarkan. Demikian pula dengan pembelajaran matematika mahasiswa harus memiliki kecakapan atau kemampuan untuk menyelesaikan soal-soal matematis. Pemecahan 
masalah matematika dilakukan tahapan-tahapan penalaran yang disebut heuristik. Heuristik merupakan cara yang menggunakan pemecah masalah dalam menemukan solusi masalah. Strategi heuristik merupakan suatu prosedur khusus untuk memecahkan masalah matematika dengan memberi penuntun atau petunjuk dalam bentuk pertanyaan atau perintah pada langkah-langkah pemecahan masalah.

Terdapat 5 langkah pemecahan masalah yang dijelaskan lebih rinci oleh Krulik dan Rudnik yaitu: membaca dan berpikir, eksplorasi dan merencanakan, memilih strategi, mencari jawaban, dan refleksi dan mengembangkan. Pendekatan heuristik Krulisk dan Rudnick terdapat langkah dalam pemecahan masalah matematika untuk menemukan solusi dari permasalahan matematika.

Faktor-faktor yang memengaruhi kemampuan penalaran matematis mahasiswa yaitu faktor internal adalah faktor yang berasal dari dalam diri individu seperti tingkat kecerdasan, sikap, minat, bakat dan kemauan serta motivasi diri dalam pembelajaran matematika. Faktor eksternal adalah faktor dari luar individu yakni kondisi lingkungan sosial dan nonsosial (rumah, gedung sekolah, dan sebagainya). Faktor pendekatan belajar yaitu segala cara atau strategi yang digunakan individu dalam menunjang keefektifan dan efisiensi proses mempelajari materi tertentu (Munandar, 2003).

Aljabar Linear Elementer termasuk salah satu cabang ilmu matematika dan memiliki beberapa materi yang membutuhkan kemampuan bernalar dalam menyelesaikan solusi dari permasalahannya. Tidak lepas dari itu, pembelajaran Aljabar Linear Elementer harus menguasai prasyarat penguasaan logika matematika dan himpunan yang terkait dari aplikasi penggunaannya dalam kehidupaan sehari-hari baik secara konkret maupun abstrak, dapat disimpulkan bahwa Aljabar Linear Elementer identik dengan penggunaan logika dan bernalar dalam pemecahan masalah dan pencarian solusi. Namun faktanya, pembelajaran Aljabar Linear Elementer memiliki konsep-konsep yang bersifat abstrak menyebabkan mahasiswa tidak mudah mengenali contoh-contoh yang berkenaan dengan konsep dan juga mahasiswa belum terbiasa dengan pembuktian deduktif, sehingga berujung pada rendahnya kualitas pemahaman mahasiswa terhadap mata kuliah Aljabar Linear Elementer.

Hasil penelitian terdahulu, menemukan beberapa masalah yang dihadapi terkait kemampuan penalaran matematis pada mata kuliah Aljabar Linear Elementer, yaitu kesulitan pada pemahaman masalah dan konsep dasar terdapat pada pemahaman membuktikan fakta-fakta yang terdapat pada persamaan linear (Nursuprianah \& Sholikhah, 2009).

Sistem persamaan linear merupakan sekumpulan persamaan linear yang terdiri dari beberapa variabel. Sistem persamaan linear adalah koleksi sebanyak berhingga persamaan-persamaan linear. Operasi Baris Elementer (OBE) adalah salah satu alternatif dalam menyelesaikan suatu bentuk matriks seperti menentukan invers matriks dan penerapan matriks pada sistem persamaan linear menggunakan dua cara yaitu Eliminasi Gauss dan Eliminasi Gauss-Jordan. Bagaimana operasi-operasi ini dapat digunakan untuk menyelesaikan sistem persamaan linear. Pada dasarnya proses persamaan linear dalam operasi baris elementer yaitu menukar letak dua baris, mengalikan suatu persamaan dengan skalar tak nol, dan menambah suatu persamaan dengan kelipatan persamaan yang lain (Anton, 1998). 
Penelitian sebelumnya oleh Nursuprianah \& Sholikhah (2009) juga menemukan bahwa faktor dominan kesulitan yang dihadapi yaitu ketidaktahuan metode penalaran; ketidakpahaman konsep; ketiga ketidaktahuan tentang logika; keempat yakni penyelesaian masalah; banyak sekali kesalahan-kesalahan yang dilakukan mahasiswa dalam menyelesaikan soal sistem persamaan linear dengan metode operasi baris elementer.

Isnaeni, Fajriyah, Risky, Purwasih, \& Hidayat (2018) menyatakan berdasarkan hasil penelitian dan analisis data yang telah diperoleh mengenai kesulitan siswa dalam menyelesaikan soal kemampuan penalaran pada materi persamaan garis lurus bahwa hal itu disebabkan oleh kurangnya pemahaman konsep dan kesulitan siswa pada kemampuan penalaran ada pada indikator merumuskan lawan contoh. Kemandirian belajar siswa terletak pada kategori baik.

Penelitian kemampuan penalaran sebelumnya telah menyarankan bahwa dalam pembelajaran mahasiswa seharusnya dimotivasi dan dibimbing untuk mengonstruksikan ide, konsep, dan pemahaman mereka sendiri mengenai materi yang dipelajari berdasarkan prior knowledge yang sudah mereka miliki. Berangkat dari permasalahan yang telah diuraikan baik berupa teori, penelitian terdahulu dan fakta di lapangan maka peneliti tertarik untuk mengangkat judul penelitian dengan rancangan judul "Analisis Kemampuan Penalaran Matematis pada Mata Kuliah Aljabar Linear Elementer Mahasiswa Pendidikan Matematika Fakultas Tarbiyah dan Keguruan UIN Alauddin Makassar.

\section{METODE PENELITIAN}

Penelitian merupakan penelitian dengan pendekatan kualitatif. Pendekatan dapat dimaknai sebagai usaha dalam aktivitas penelitian untuk mengadakan hubungan-hubungan dengan objek yang diteliti (Hadari \& Martini, 1995). Pendekatan merupakan upaya untuk mencapai target yang sudah ditentukan dalam tujuan penelitian. Pendekatan ilmiah yang digunakan yakni pendekatan psikologis dan studi kasus. Berdasarkan rumusan masalah penelitian, maka penelitian ini dikategorikan ke dalam penelitian deskriptif kualitatif yaitu mendeskripsikan suatu gejala, peristiwa, kejadian yang terjadi saat sekarang.

Penelitian ini dilaksanakan di Universitas Islam Negeri Alauddin Makassar Fakultas Tarbiyah dan Keguruan Jurusan Pendidikan Matematika, dengan sumber data adalah mahasiswa semester II angkatan 2017 yang berjumlah 72 orang.

Teknik pengumpulan data yang digunakan dalam penelitian ini yaitu tes tertulis, wawancara dan dokumentasi. Teknik pengumpulan data tersebut dapat diharapkan saling melengkapi sehingga diperoleh suatu informasi yang diharapkan. Keabsahan data dalam penelitian ini meliputi uji credibility (validitas internal), transferbility (validitas eksternal), dependability (reliabilitas), dan confirmability (obyektivitas) (Sugiyono, 2014). Untuk menguji kredibilitas data dengan triangulasi teknik, yaitu dilakukan dengan cara mengecek data kepada sumber yng sama dengan teknik yaang berbeda. Misalnya untuk mengecek data melalui tes tertulis, wawancara dan dokumentasi. Setelah penulis melakukan penelitian dengan menggunakan metode tes tertulis wawancara, dan dokumentasi, kemudian data hasil dari penelitian itu digabungkan sehingga saling melengkapi.

Statistik yang digunakan untuk analisis data yaitu statistik deskriptif. Data yang disajikan dalam penelitian ini berbentuk rangkuman secara deskriptif dan sistematis dari hasil yang diperoleh, sehingga informasi yang kompleks dapat diketahui dengan mudah. Penarikan kesimpulan apabila data-data tersebut telah melalui proses verifikasi atau proses 
pembuktian kembali yang dimaksudkan untuk mencari pembenaran dan persetujuan sehingga validitas dapat tercapai.

\section{HASIL DAN PEMBAHASAN}

Penelitian ini dilaksanakan di Jurusan Pendidikan Matematika Fakultas Tarbiyah dan Keguruan UIN Alauddin Makassar pada mahasiswa semester II Jurusan Pendidikan Matematika. Soal tes diberikan kepada mahasiswa yang berjumlah 72 orang. Soal yang diberikan masing-masing 5 nomor untuk menguji kemampuan penalaran yang sebelumnya divalidasi terlebih dahulu oleh validator agar data yang dihasilkan tepat pada sasaran penelitian dan menjawab pertanyaan penelitian. Berikut akan dideskripsikan kemampuan penalaran matematis mahasiswa dalam menyelesaikan soal-soal Aljabar Linear Elementer.

Berdasarkan hasil tes kemampuan penalaran matematis mahasiswa dari 72 Siswa dalam menyelesaikan soal Aljabar Linear Elementer untuk menguji kemampuan penalaran yang dilakukan oleh mahasiswa dengan masing-masing soal-soal memiliki indikator dan sub indikator kemampuan penalaran. Dari hasil tes tingkat kemampuan penalaran mahasiswa tergolong cukup meskipun masih ada kemampuan-kemampuan yang dikategorikan rendah. Hal ini dapat kita lihat dari data yang akan disajikan hasil tes kemampuan penalaran mahasiswa

Tabel 1. Data Hasil Tes Kemampuan Penalaran Matematis Mahasiswa Semester II Jurusan Pendidikan Matematika berdasarkan indikator

\begin{tabular}{clcc}
\hline No & \multicolumn{1}{c}{$\begin{array}{c}\text { Indikator Kemampuan Penalaran } \\
\text { Matematis }\end{array}$} & Persentase & Kategori \\
\hline 1. & Menarik kesimpulan logis & $76,53 \%$ & Tinggi \\
2. & Memberikan penjelasan dengan & $40,55 \%$ & Sedang \\
& menggunakan fakta dan pola suatu konsep & & \\
3. & Memperkirakan jawaban dan solusi & $37,50 \%$ & Sedang \\
\hline & Jumlah rata-rata & $51,52 \%$ & Sedang \\
\hline
\end{tabular}

Berdasarkan tabel 1, persentase dari kemampuan penalaran matematis mahasiswa semester II Jurusan Pendidikan Matematika Fakultas Tarbiyah dan Keguruan UIN Alauddin Makassar jika dirata-ratakan berdasarkan skor yang diperoleh untuk setiap indikator kemampuan penalaran matematis berada pada kategori sedang dan hampir memenuhi kriteria kemampuan penalaran matematis yaitu sebesar 51,52\%, meskipun belum optimal karena terdapat indikator yang berada pada kategori sedang yaitu indikator memberikan penjelasan dengan menggunakan fakta dan pola suatu konsep dan memperkirakan jawaban dan solusi. Sehingga keseluruhan kemampuan penalaran matematis mahasiswa jika dirataratakan berada pada kategori sedang.

Dalam menggunakan pola dan hubungan untuk menganalisa situasi matematis. Subjek mampu menyelesaikan soal dengan menggunakan pola dan hubungan yang terdapat pada soal dengan tepat dan lancar. Hal ini sesuai dengan penelitian Suprihatin,dkk. yang menyatakan bahwa siswa yang memiliki kemampuan penalaran matematis dalam kategori tinggi memiliki kemampuan yang baik dalam menemukan pola dari suatu permasalahan (Suprihatin, Maya, \& Senjayawati, 2018). 
Tabel 2. Persentase Hasil Tes Kemampuan Penalaran Matematis Mahasiswa Semester II Jurusan Pendidikan Matematika

\begin{tabular}{ccccc}
\hline No. & Interval & Frekuensi & Persentase (\%) & Kategori \\
\hline 1 & $0-30$ & 14 & 19 & Rendah \\
\hline 2 & $31-70$ & 27 & 38 & Sedang \\
\hline 3 & $71-100$ & 31 & 43 & Tinggi \\
\hline & Jumlah & 72 & 100 & \\
\hline
\end{tabular}

Dari tabel 2 terlihat bahwa persentase skor hasil tes kemampuan penalaran matematis mahasiswa sebesar $19 \%$ berada pada kategori rendah, $38 \%$ berada pada kategori sedang, 43\% berada pada kategori tinggi. Di samping itu, sesuai dengan skor ratarata hasil kemampuan tes penalaran matematis mahasiswa sebesar 54,33, jika dikonversi pada tabel ternyata berada dalam kategori sedang. Hal ini berarti rata-rata hasil kemampuan penalaran matematis mahasiswa semester II Jurusan Pendidikan Matematika berada pada kategori sedang meskipun belum dapat dikatakan optimal. Berikut ini penulis sajikan diagram batang untuk lebih memperjelas gambaran keadaan hasil tes kemampuan penalaran matematis mahasiswa semester II Jurusan Pendidikan Matematika Fakultas Tarbiyah dan Keguruan UIN Alauddin Makassar.

Siswa dengan kemampuan penalaran matematis dalam indikator kemampuan mengajukan dugaan mampu menuliskan hal-hal yang diketahui dan ditanyakan pada masalah yang disajikan serta menuliskan rumus inti yang digunakan dalam pemecahan masalah. Dalam indikator kemampuan melakukan manipulasi matematika mampu menuliskan langkah-langkah pemecahan masalah dan melakukan operasi aljabar dengan menemukan hasil akhir yang diminta soal. Tidak mampu menuliskan kesimpulan dengan baik dan benar (Wulandari, 2020).

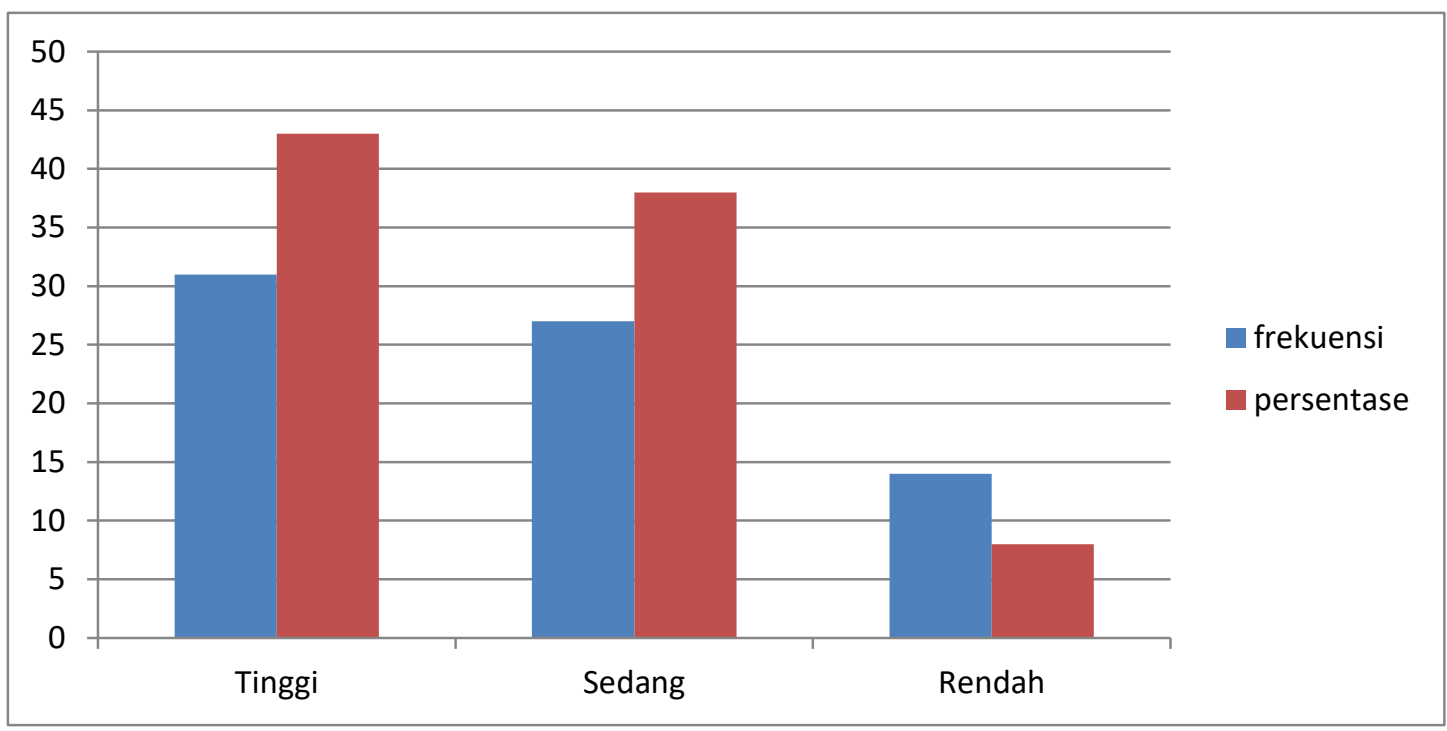

Gambar 1. Diagram Batang Hasil Tes Kemampuan Penalaran Matematis Mahasiswa Semester II Jurusan Pendidikan Matematika

Selain melakukan tes tertulis peneliti melakukan wawancara terhadap mahasiswa tersebut untuk mendapatkan informasi bagaimana cara mengerjakan soal dan faktor-faktor yang memengaruhi kemampuan penalaran mahasiswa dalam menyelesaikan soal 
kemampuan penalaran pada mata kuliah Aljabar Linear Elementer pokok bahasan sistem persamaan linear dan operasi baris elementer, sehingga dapat diterapkan pada mahasiswa lain. Mahasiswa yang saya jadikan sampel yang mewakili subjek penelitian untuk diwawancarai adalah mahasiswa yang masing-masing berada pada kategori tinggi, sedang dan rendah dalam menjawab soal tes kemampuan penalaran mahasiswa agar hambatan yang dihadapi benar-benar dapat diketahui serta diminimalisir dan faktor penunjangnya dapat ditingkatkan.

Kemampuan penalaran siswa berbeda. Guru matematika sebaiknya mengetahui kemampuan matematika siswa agar dapat mengembangkan penalaran matematis siswa, karena setiap tingkat kemampuan penalaran berbeda-beda. Guru juga diharapkan agar selalu melatih atau membiasakan siswa agar menuliskan apa yang diketahui dan ditanyakan dalam soal sebelum menyelesaiakan tugas harian, ulangan, ujian, dan lain sebagainya dan Siswa diharapkan agar selalu aktif dalam melaksanakan pembelajaran matematika, sehingga kemampuan penalaran matematis siswa akan semakin meningkat (Hamsiah \& Kurniawan, 2017),

Berdasarkan hasil tes ditemukan bahwa kemampuan penalaran matematis mahasiswa berada dalam kategori sedang hal ini dikarenakan masih ditemukan indikator yang masih tergolong rendah. Dari indikator inilah peneliti mengadakan wawancara untuk mengetahui faktor-faktor yang memengaruhi terhambatnya kemampuan penalaran matematis mahasiswa.

Berdasarkan hasil wawancara dengan beberapa mahasiswa, diperoleh beberapa faktor yang memengaruhi kemampuan penalaran matematis mahasiswa pada mata kuliah Aljabar Linear Elementer. Faktor yang berasal dari sisi internal mahasiswa, diantaranya minat merupakan salah satu faktor yang menentukan tinggi atau rendahnya kemampuan penalaran matematis mahasiswa karena tergantung dari bagaimana sikap mahasiswa dalam proses belajar mengajar. terlihat bahwa mahasiswa yang memiliki minat dalam bidang ini, akan dengan mudah dalam mempelajarinya sehingga berakibat pada pemahaman mahasiswa mengenai materi yang diajarkan dosen. selain itu dapat pula dilihat dari hasil tes mahasiswa yang memiliki kemampuan penalaran matematis memiliki hasil belajar baik begitupun sebaliknya. Faktor yang berasal dari eksternal mahasiswa, diantaranya: S026 dalam proses pembelajaran dibutuhkan perangkat yang menunjang tercapainya tujuan pembelajaran. Salah satu faktor yang menentukan proses pembelajaran berjalan dengan baik adalah kemampuan dosen menjelaskan materi pembelajaran baik dari segi penguasaan materi maupun kejelasan dalam menerangkan materi Aljabar Linear Elementer. Lingkungan belajar menjadi salah satu faktor yang memengaruhi tingkat kemampuan seseorang dalam bernalar atau berpikir.

Berdasarkan hasil tes dan wawancara pada kemampuan penalaran yang dilakukan pada mahasiswa semester II Jurusan Pendidikan Matematika Fakultas Tarbiyah dan Keguruan UIN Alauddin Makassar dalam menyelesaikan soal pada materi Aljabar Linear Elementer. Hasil tes yang diperoleh mahasiswa dalam menyelesaikan 5 butir soal menunjukkan bahwa kemampuan menarik kesimpulan logis berdasarkan hasil presentasi dikategorikan tinggi, memberikan penjelesan dengan menggunakan fakta dan pola suatu konsep dikategorikan rendah, serta kemampuan memperkirakan jawaban dan solusi dalam menyelesaikan soal kemampuan penalaran matematis mahasiswa dikategorikan rendah. Wade dan Tavris mengatakan bahwa penalaran adalah suatu aktivitas mental yang 
melibatkan penggunaan berbagai informasi yang bertujuan untuk mencapai suatu kesimpulan. Berbeda dengan respon tidak sadar, penalaran mangharuskan kita menggambarkan secara spesifik hasil yang kita dapat dari observasi, fakta maupun dugaan (Wade \& Traves, 2017). Penalaran dilakukan melalui proses berpikir yang berusaha untuk menghubungkan konsep matematika yang telah dimiliki seseorang kemudian disimpulkan menjadi sebuah pernyataan baru

Hal ini disebabkan karena mahasiswa kurang memahami bentuk soal yang diberikan. Kemampuan penalaran mahasiswa dalam kategori sedang hal ini karena masih terdapat banyak kekeliruan. Kekeliruan mahaiswa terjadi ketika dihadapkan pada topik Operasi Baris Elementer. Pada topik menentukan solusi Eliminasi Gauss dan Eliminasi Gauss Jordan serta menentukan Invers suatu matriks elementer mahasiswa kesulitan menentukan langkah awal yaitu menarik kesimpulan untuk menentukan solusi dari suatu matriks. Dalam menganalisis jenis solusi yang dimiliki Sistem Persamaan Linear berdasarkaan matriks elementer tereduksi dibutuhkan kemampuaan mahasiswa dalam menentukan langkah awal yaitu menarik kesimpulan logis untuk menyelesaikan langkahlangkah operasi baris elementer.

Terdapat persamaan antara subjek dalam memperkirakan proses penyelesaian soal berbasis masalah, keduanya mampu memperkirakan proses penyelesaian, keduanya mampu memperkirakan langkah-langkah apa saja yang akan dilakukan untuk menyelesaikan soal yang diberikan. Hal ini sesuai bahwa siswa dengan kemampuan penalaran matematis tinggi mampu memperkirakan langkah-langkah untuk menyelesaikan soal serta memberikan penjelasan perkiraan yang dibuat (Hidayati \& Widodo, 2015).

Kemampuan mahasiswa dalam menginterpretasi soal matematis mempengaruhi tingkat kemampuan penalaran matematisnya. Selain itu juga diperlukan kemampuan mahasiswa dalam menyusun suatu pola matematis berdasarkan pola matematis yang ada pada sistem persamaan linear dan matriks elementer. Dalam hal ini, kemampuan pemahaman matematis dalam memahami konsep atau topik matematis secara komprehensif juga memengaruhi kemampuan penalaran matematis mahasiswa.

Selain melakukan tes dalam bentuk uraian peneliti melakukan wawancara untuk mendukung kesahihan dari suatu analisis kemampuan penalaran matematis. Untuk mengetahui faktor-faktor yang memengaruhi kemampuan penalaran matematis mahasiswa dalam menyelesaikan soal yang diberikan. Banyaknya kelemahan yang ditunjukkan mahasiswa dalam pengerjaan soal tes kemampuan penalaran matematis menjadi evaluasi bagi mahasiswa selaku pihak yang belajar maupun dosen selaku pihak yang mengajar. Kelemahan ini dapat menjadi acuan agar mengetahui faktor-faktor yang memengaruhi kemampuan penalaran matematis mahasiswa. Pada tahap ini, penulis melakukan wawancara dengan beberapa mahasiswa untuk mengetahui faktor-faktor tersebut.

Beberapa mahasiswa menyatakan bahwa mata kuliah Aljabar Linear Elementer merupakan mata kuliah yang membutuhkan konsentrasi yang tinggi karena membutuhkan daya nalar atau daya berpikir yang cukup tinggi untuk menemukan solusi atau pemecahan masalah dalam soal-soalnya. Data yang terkumpul dalam penelitian ini menunjukkan fakta mengenai ragam kesulitan mahasiswa dalam memahami konsep Sistem Persamaan Linear dan Operasi Baris Elementer. Ragam kesulitan yang dialami mahasiswa secara umum yaitu sulit dalam menentukan langkah pertama untuk membuktikan suatu teorema, sifat, 
maupun pernyataan yang harus diselidiki kesahihannya, sehingga proses bernalar mereka menjadi terhambat serta tidak mampu membuktikan suatu teorema, sifat maupun menyelidiki kebenaran dari suatu pernyataan. Hal ini sejalan dengan hasil penelitian yang dilakukan oleh Cita Dwi Rosita, yaitu kesulitan pada pemahaman konsep dasar terdapat padaa pemahaman membuktikan fakta-fakta yang terdapat pada persamaan linear (Rosita, Laelasari, \& Noto, 2014).

Selain dari fakta yang dikemukakan di atas yaitu terkait kemampuan jika diselaraskan berdasarkan hasil wawancara ada beberapa faktor yang memengaruhi proses kemampuan mahasiswa dalam bernalar yaitu faktor internal dan faktor eksternal. Faktor internal yaitu minat yang kurang. Minat merupakan kemauan akan sesuatu atau kecenderungan seseorang dalam menerima sesuatu. Semakin besar minat seseorang akan suatu hal semakin besar pula penyerapan. Konsep-konsep yang abstrak pada mata kuliah aljabar linear elementer membutuhkan konsentrasi yang tinggi, sehingga hal ini memicu kurangnya minat mahasiswa dalam mempelajari materi aljabar linear terutama jika itu berkaitan dengan operasi baris elementer. Hal ini dikarenakan mahasiswa sulit menentukan langkah awal karena kurangnya pemahaman konsep.

Johar (2017) menjelaskan ada beberapa cara yang bisa dilakukan guru untuk meningkatkan kemampuan siswa dalam menyelesaikan masalah, misalnya jika siswa frustasi atau bingung menemukan strategi pemecahan masalah guru bisa memberikan katakata motivasi, seperti 'coba dulu, kamu pasti bisa', 'ayo tetap semangat', 'ibu yakin kamu mampu menjawabnya', 'kamu boleh menggambar, membuat tabel, atau mencoba-coba'. Selain itu guru juga memberikan clue (petunjuk terbatas) agar siswa memulai penyelesaian masalah dan memberikan contoh soal yang serupa.

Selain itu, faktor lain yang membuat siswa kesulitan dalam mengerjakan soal aljabar antara lain kurangnya persiapan siswa dalam menjawab soal tersebut, hal ini dikarenakan soal langsung diberikan ke siswa tanpa diberitahukan terlebih dahulu. Namun, hal ini terlihat bahwa guru belum sering memberikan soal-soal yang sesuai pada saat pembelajaran, sehingga siswa tidak terbiasa dalam mengerjakan soal yang menuntut kemampuan penalaran yang tinggi seperti soal aljabar (Nuralam \& Maulidayani, 2020),

Faktor eksternal yang memengaruhi kemampuan penalaran matematis mahasiswa adalah referensi atau bahan ajar (modul) yang digunakan. Penggunaan bahan ajar mata kuliah aljabar linear elementer yang sesuai dengan kapasitas mahasiswa akan mempermudah mahasiswa dalam mempelajari materi-materi aljabar linear elemneter. Faktor eksternal lainnya tidak terlepas dari kemampuan dosen dan metode yang digunakan dalam mengajar agar penyampaian pembelajaran lebih menyeluruh, selain itu faktor lainnya bisa juga dikarenakan lingkungan yang tidak kondusif seperti yang diutarakan salah satu mahasiswa pada saat wawancara kadang banyak mahasiswa yang ribut dalam proses pembelajaran yang membuat sebagian kecil mahasiswa merasa terganggu sehingga tidak konsentrasi dalam menyerap ilmu. Selain itu lingkungan yang kondusif juga akan memengaruhi tingkat kemampuan mahasiswa dalam bernalar.

Faktor yang memengaruhi kemampuan penalaran matematis yaitu faktor internal dan faktor eksternal. Faktor internal yaitu minat kemudian untuk faktor eksternal yaitu perangkat pembelajaran, peran dosen dan lingkungan belajar. Hal ini sejalan dengan teori dalam buku Utami Munandar yang menyatakan bahwa kemampuan penalaran matematis mahasiswa dipengaruhi oleh faktor internal dan eksternal. Salah satu dari faktor internal 
yang sesuai dengan teori yaitu minat, dan faktor eksternal yaitu kondisi lingkungan, dan faktor pendekatan pembelajaran dalam hal ini adalah peran dosen.

Jika dirunutkan yang menyebabkan kurangnya minat mahasiswa dalam melakukan penalaran matematis pada mata kuliah Aljabar Linear Elementer yaitu berasal dari faktor eksternal. Pengaruh dari faktor eksternal tersebutlah yang menyebabkan kedalam faktor internal yang mengakibatkan kurang minatnya mahasiswa pada mata kuliah Aljabar Linear Elementer.

Faktor eksternal yang memengaruhi kemampuan penalaran matematis mahasiswa adalah referensi atau bahan ajar (modul) yang digunakan. Penggunaan bahan ajar mata kuliah aljabar linear elementer yang sesuai dengan kapasitas mahasiswa akan mempermudah mahasiswa dalam mempelajari materi-materi aljabar linear elemneter. Faktor eksternal lainnya tidak terlepas dari kemampuan dosen dan metode yang digunakan dalam mengajar agar penyampaian pembelajaran lebih menyeluruh terkhusus pada materi dasar tentang Sistem Persamaan Linear dan Operasi Baris Elementer, selain itu faktor lainnya seperti lingkungan yang tidak kondusif ketika diutarakan salah satu mahasiswa pada saat wawancara kadang banyak mahasiswa yang ribut dalam proses pembelajaran yang membuat sebagian kecil mahasiswa merasa terganggu sehingga tidak konsentrasi dalam menyerap ilmu. Apabila faktor-faktor di atas diminimalisirkan, maka akan menjadi pendukung yang memengaruhi kemampuan penalaran matematis mahasiswa.

\section{SIMPULAN}

Kemampuan penalaran matematis mahasiswa semester II Jurusan Pendidikan Matematika Fakultas Tarbiyah dan Keguruan UIN Alauddin Makassar berada pada kategori sedang. Berdasarkan indikator kemampuan penalaran matematis mahasiswa jika dirataratakan persentasenya adalah 51,52\%. Meskipun terbilang sedang, masih banyak kemampuan-kemampuan yang ditemukan masih tergolong rendah. Indikator yang paling tinggi berada pada kemampuan menarik kesimpulan logis yaitu sebesar 76,53\%.

Faktor-faktor yang memengaruhi kemampuan penalaran matematis pada mata kuliah Aljabar Linear Elementer mahasiswa semester II Jurusan Pendidikan Matematika Fakultas Tarbiyah dan Keguruan UIN Alauddin Makassar adalah faktor internal yaitu minat dan konsentrasi. Selanjutnya faktor eksternal yaitu perangkat pembelajaran, peran dosen dan lingkungan belajar.

\section{DAFTAR PUSTAKA}

Anton, H. (1998). Aljabar linier elementer. Jakarta: Erlangga.

Hadari, \& Martini. (1995). Instrumen penelitian bidang sosial. Gajah Mada University Press.

Hamsiah, Masjudin, \& Kurniawan, A. (2017). Analisis kemampuan penalaran matematis siswa SMPN 13 Mataram pada materi bangun ruang. Media Pendidikan Matematika, 5(2), 115-123. https://doi.org/10.33394/mpm.v5i2.1462

Hidayati, A., \& Widodo, S. (2015). Proses penalaran matematis siswa dalam memecahkan masalah matematika pada materi pokok dimensi tiga berdasarkan kemampuan siswa di SMA Negeri 5 Kediri. Jurnal Math Educator Nusantara, 1(2), 131-143.

Isnaeni, S., Fajriyah, L., Risky, E. S., Purwasih, R., \& Hidayat, W. (2018). Analisis kemampuan penalaran matematis dan kemandirian belajar siswa SMP pada materi persamaan 
garis lurus. Journal of Medives: Journal of Mathematics Education IKIP Veteran Semarang, 2(1), 107-116. https://doi.org/10.31331/medives.v2i1.528

Johar, R. (2011). The teachers' efforts to encourage the students' strategies to find the solution of fraction problem in banda Aceh. In Proceeding of 24th International Congress for School Effectiveness and Improvement. Cyprus.

Kesumawati, N. (2010). Peningkatan kemampuan pemahaman, pemecahan masalah dan disposisi matematis siswa SMP melalui pendekatan matematika realistik. In Universitas Pendidikan Indonesia.

Munandar, U. (2003). Psikologi belajar. Jakarta: Grafindo Persada.

Nuralam, \& Maulidayani. (2020). Capaian kemampuan penalaran matematis siswa dengan model AIR. Jurnal Numeracy, 7(1), 35-48. https://doi.org/10.46244/numeracy.v7i1.997

Nursalam, Angriani, A. D., \& Usman, H. (2017). Pengembangan tes kemampuan penalaran matematis peserta didik madrasah tsanawiyah di Makassar. Lentera Pendidikan, 20(1), 85-97. https://doi.org/10.24252/lp.2017v20n1a7

Nursuprianah, I., \& Sholikhah, M. (2009). Analisis kesulitan mahasiswa dalam memahami mata kuliah aljabar matriks (studi kasus pada semester IV tadris matematika tahun akademik 2008/2009 di STAIN Cirebon). EduMa, 1(1), 75-84.

Rosita, C. D., Laelasari, \& Noto, M. S. (2014). Analisis kemampuan pemahaman matematis mahasiswa pada mata kuliah aljabar linier 1. Euclid, 1(2), 60-69. https://doi.org/10.33603/e.v1i2.345

Sariningsih, R., \& Purwasih, R. (2017). Pembelajaran problem based learning untuk meningkatkan kemampuan pemecahan masalah matematis dan self efficacy mahasiswa calon guru. JNPM (Jurnal Nasional Pendidikan Matematika)Jurnal Nasional Pendidikan Matematika, 1(1), 163-177. https://doi.org/10.33603/jnpm.v1i1.275

Sriyanto. (2007). Strategi sukses menguasai matematika. Yogyakarta: Indonesia Cerdas.

Sugiyono. (2014). Metode penelitian kuantitatif, kualitatif dan R\&D. Bandung: Alfabeta.

Suharnan. (2005). Psikologi kognitif. Surabaya: Srikandi.

Sumarmo. (2016). Pedoman pemberian skor pada beragam tes kemampuan matematika. STKIP Siliwangi.

Suprihatin, T. R., Maya, R., \& Senjayawati, E. (2018). Analisis kemampuan penalaran matematis siswa SMP pada materi segitiga dan segiempat. Jurnal Kajian Pembelajaran Matematika, 2(1), 9-13.

Wade, C., \& Traves, C. (2017). Psikologi. Jakarta: Erlangga.

Wulandari, F. A. (2020). Analisis kemampuan penalaran matematis ditinjau dari gaya belajar siswa kelas VII MTs. Negeri 3 Bulukumba. Universitas Muhammadiyah Makassar. 